\title{
Letter
}

\section{Storage of dissolved organic carbon in Chinese glaciers}

\section{INTRODUCTION}

Recently, attention has been focused on the storage and cycling of organic carbon (OC) in glaciers and ice sheets because of their high vulnerability to a warming climate (Bhatia and others, 2013; Hood and others, 2015). Dissolved OC (DOC) in glaciers and ice sheets is an important element in the cycling of carbon between the oceans and land (Hood and others, 2009; Stubbins and others, 2012; Spencer and others, 2014), and has important implications for the biogeochemical cycling of aquatic system because of its high bioavailability for aquatic heterotrophs (Singer and others, 2012; Lawson and others, 2014a, b).

The mountain glaciers of China are at the headwaters of many large Asian rivers (e.g. the Yangtze, Indus and Ganges). It is important to understand the storage and cycling of DOC in these glaciers, so that biogeochemical changes due to global warming can be understood. Hood and others (2015) used previously published data to estimate the amount of DOC stored globally in glaciers and ice sheets, to be $4.48 \pm 2.79 \mathrm{Pg}$. However, DOC data from the high mountain glaciers of Asia (including the glaciers in western China) were from only one sampling site. In the present study, using snow/ice samples collected from four glaciers in different regions of western China and an updated Chinese glacier inventory (Guo and others, 2014), we estimate the storage of DOC in Chinese glaciers and the annual DOC deposition and release rates.

\section{METHODS}

Field campaigns on four alpine glaciers of western China were conducted in August, 2014 (Table 1). The glaciers were Tien Shan Glacier No. 1 (TS), Laohugou Glacier No. 12 (LHG), Dongkemadi Glacier (DKMD) and Baishui Glacier No. 1 at Yulong Mountain (YL) (Fig. 1). The climate in north western China and the central part of the Tibetan Plateau (TP) is strongly dominated by westerlies and the Asian winter monsoon during winter, and weakly by the Asian summer monsoon during summer. The climate of the southern TP is strongly dominated by the Asian monsoon during summer and weakly by westerlies during winter. Glaciers of different regions can be categorized into different types based on air temperature at the equilibrium line altitude during summer and the amount of annual precipitation (Shi and Liu, 2000). YL is classed as a maritime glacier due to high summer average air temperature $\left(1-5^{\circ} \mathrm{C}\right)$ and abundant annual precipitation (1000-3000 mm w.e.). DKMD is a polar glacier due to low summer air temperature $\left(<-1^{\circ} \mathrm{C}\right)$ and low annual precipitation (200-500 $\mathrm{mm}$ w.e.). TS is a continental glacier due to relatively high summer air temperature $\left(0-3^{\circ} \mathrm{C}\right)$ and medium amount of precipitation (500-1000 mm w.e.), while LHG is at the transition region between a polar glacier and continental glacier. These four glaciers therefore represent the spectrum of glacier types found in China.
Surface $(\sim 10 \mathrm{~cm})$ snow/ice samples were collected from both the ablation and accumulation areas of each glacier along a transect from low to high elevation at 50-100 m elevation intervals. A snow pit was dug and sampled at $\sim 5-10 \mathrm{~cm}$ resolution in the accumulation zone of each glacier, apart from YL. At each elevation interval, 2 or 3 parallel surface samples were collected at the different sites and all samples were stored in Whirl-Pak ${ }^{\circledR}$ bags and kept at below $0^{\circ} \mathrm{C}$ during transport (1-2 d). In each glacier, $\sim 30$ surface snow/ice samples were collected and for convenience, the samples at each glacier were divided into three zones (zone1, zone2, zone3) based on the elevation, i.e. zone1 at the lowest elevation, zone3 at the highest elevation. The number of samples in each zone varied from 6 to 16 .

The DOC concentration in each sample was determined using a Vario EL CN analyser (Elementar, Hanau, Germany). The sample was passed through a $0.45 \mu \mathrm{m}$ Acrodisc syringe filter (Pall Life Sciences, Ann Arbor, MI, USA) and then acidified with $100 \mu \mathrm{L}$ of $10 \%$ hydrochloric acid to remove inorganic carbonates. Non-purgeable OC was then oxidized by combusting the sample at $850^{\circ} \mathrm{C}$ in a carrier gas with a controlled $\mathrm{O}_{2}$ concentration, and the evolved gases containing carbon were converted to $\mathrm{CO}_{2}$, which was determined using a non-dispersive infrared analyser. The system was calibrated using a potassium hydrogen phthalate standard. The detection limit for DOC was $\sim 50$ $\mu g \mathrm{CL}^{-1}$ defined as three times the standard deviation of low concentration samples. The reproducibility (the relative deviation from the mean value) was better than $5 \%$.

In addition, inorganic ionic species were determined for snow pit samples using two ionic chromatography (IC) systems (881 Compact IC Pro, Metrohm, Herisau, Switzerland) (Xu and others, 2015). One of the IC systems was used to determine cations, and was equipped with a Metrosep C4 guard/2.0 column and Metrosep C4 250/2.0 column (Metrohm), which were kept at $30^{\circ} \mathrm{C}$ during measurements. The other IC system, equipped with a Metrosep RP2 guard/3.6 column and a Metrosep A Supp15 250/4.0 column (Metrohm), and kept at $45^{\circ} \mathrm{C}$ during measurements, was used to determine anions.

\section{CHARACTERISTICS OF THE DOC DISTRIBUTIONS IN THE GLACIERS}

The average mass concentration of DOC decreases from zone1 $\left(987-1470 \mu g \mathrm{CL}^{-1}\right)$ to zone3 $\left(737-1030 \mu \mathrm{gC} \mathrm{L}^{-1}\right)$ in TS and LHG (Fig. 1), probably because of the debris-rich surface and strong microbial activity (such as snow algae, mirofauna, insects and bacteria thrive) at the low elevation areas of the glaciers (Takeuchi and Li, 2008). Organisms combining with mineral dust to form spherical granules, cryoconite, usually have high DOC concentration (1000-3000 $\mathrm{ggC} \mathrm{L}^{-1}$ ) (Anesio and others, 2010). The DOC concentrations in zone1 at DKMD and YL were lower than in zone2 and zone3; the reason for this trend remains uncertain at this stage, but possible explanations include strong leaching processes at zone1. The lowest DOC concentrations were found in snow pit samples $\left(500-700 \mu g \mathrm{CL}^{-1}\right)$. DOC mass concentrations at different zones in $\mathrm{YL}$ were less varied compared with those of other glaciers, likely because of strong 
Table 1. Summary of the location, sampling date, glacier length and snow pit depth in the field study in western China during 2014

\begin{tabular}{|c|c|c|c|c|c|c|}
\hline Glacier name & $\begin{array}{l}\text { Lat. } \\
\mathrm{N}\end{array}$ & $\begin{array}{l}\text { Long. } \\
\text { E }\end{array}$ & Sampling date & $\begin{array}{l}\text { Length } \\
\text { km }\end{array}$ & $\begin{array}{l}\text { Elevation } \\
\text { m a.s.l. }\end{array}$ & $\begin{array}{l}\text { Bottom depth } \\
\mathrm{cm}\end{array}$ \\
\hline TS & $43.11^{\circ}$ & $86.81^{\circ}$ & 31 August 2014 & 2.41 & 4024 & 120 \\
\hline LHG & $39.43^{\circ}$ & $96.56^{\circ}$ & 8 August 2014 & 9.85 & 4990 & 50 \\
\hline DKMD & $33.01^{\circ}$ & $92.01^{\circ}$ & 19 August 2014 & 2.8 & 5730 & 120 \\
\hline YL & $27.1^{\circ}$ & $100.2^{\circ}$ & 17 August 2014 & 2.26 & 4747 & NA \\
\hline
\end{tabular}

surface melting redistributing water soluble chemical matter throughout the whole glacier surface. The different DOC concentrations for the same zones on different glaciers could reflect the states of melting, debris cover and microbial activity for each glacier. The average DOC mass concentrations in the snow pit samples from TS $\left(519.7 \pm 136.3 \mu \mathrm{gC} \mathrm{L}^{-1}\right)$, LHG $\left(658.7 \pm 78.9 \mu \mathrm{gC} \mathrm{L}^{-1}\right)$ and DKMD $\left(642.3 \pm 499.1 \mu \mathrm{gC} \mathrm{L}^{-1}\right)$ were comparable (Fig. 1). In contrast, the concentrations of mineral dust (determined from the concentrations of $\mathrm{Ca}^{2+}$ and $\mathrm{Mg}^{2+}$ ) found in snow pit samples from TS and LHG are significantly higher $(p<0.05, t$-test), than for DKMD $(\sim 3000$ vs $\sim 400 \mu \mathrm{g} \mathrm{L}^{-1} ;$ Fig. 2). These results suggest that mineral dust may not be a major source of DOC in the glaciers. The average DOC mass concentrations across all samples in each glacier were $757.7 \pm 191.6 \mu \mathrm{gC} \mathrm{L}^{-1}$ (TS), $1096.8 \pm$ $344.8 \mu \mathrm{gC} \mathrm{L}^{-1}$ (LHG), $906.5 \pm 201.4 \mu g \mathrm{CL}^{-1}$ (DKMD) and $1263.6 \pm 85.2 \mu \mathrm{gC} \mathrm{L}^{-1}(\mathrm{YL})$. The high DOC concentration at $\mathrm{YL}$ is likely due to significant melting, which may favour microbial activity in liquid water. Yao and others (2012) showed that glaciers in the Mount Hendduanshan area (where $\mathrm{YL}$ is located) have melted more in recent decades than glaciers in other parts of western China.

The DOC concentrations in the snow pit samples at these glaciers were higher than found in other alpine glaciers, such as in Europe $\left(10-300 \mu \mathrm{gC} \mathrm{L}^{-1}\right)$ (Legrand and others, 2013, and reference therein), probably because of different methods of DOC analysis (Bisutti and others, 2004) and higher aerosol loading in Asia than in Europe (e.g. Spracklen and others, 2011). Satellite observations have shown that pollution in South and East Asia, which is the predominant aerosol source for alpine areas of western China (Zhang and others, 2015), is most severe during winter and spring (Ramanathan and others, 2001). The organic aerosol signal of biomass burning from South Asia has also been detected in Himalayan snow pit samples (Xu and others, 2013).

\section{ESTIMATING THE AMOUNT OF DOC STORED IN CHINESE GLACIERS}

Four regions in western China have been delineated based on glacier category, surface area and volume within each region (Table 2). Glacier volume in each region was first converted to w.e. mass using an ice density of $0.85 \mathrm{~g} \mathrm{~cm}^{-3}$, then the amount of DOC stored in the glaciers in each region was determined from the mass of water in the glaciers and the average DOC concentration in the glacier studied in that region (Table 2). The total amount of DOC stored was found to be $\sim 3.96 \pm 0.87 \mathrm{Tg}$. More DOC $(1.84 \pm 0.58 \mathrm{Tg})$ was stored in glaciers in the northern part of the TP than in other regions studied, and the amount decreased from the southwest TP $(0.98 \pm 0.07 \mathrm{Tg})$, to the southern TP $(0.68 \pm$ $0.15 \mathrm{Tg})$ and northwest China $(0.46 \pm 0.12 \mathrm{Tg})$. The amount
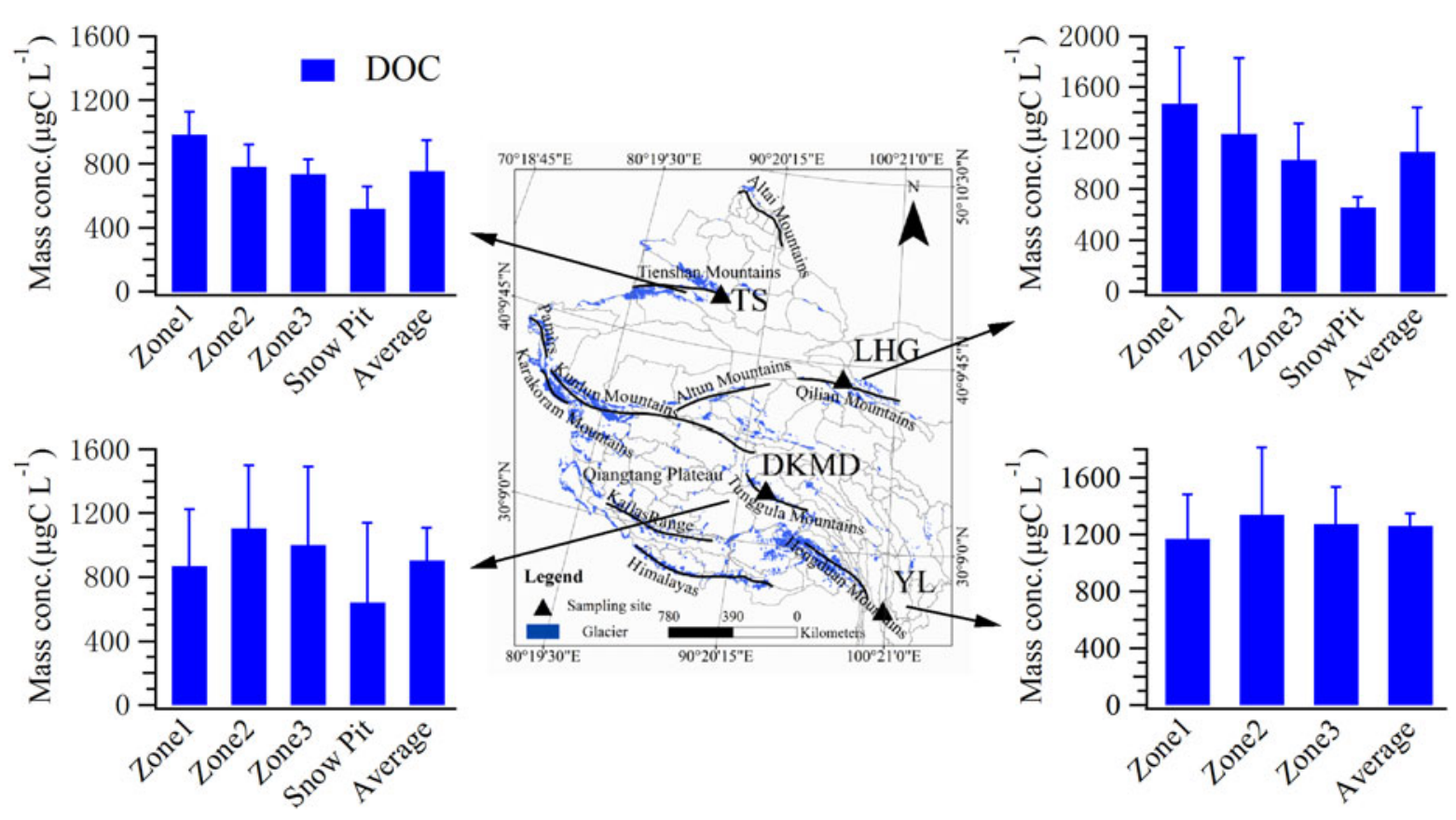

Fig. 1. Location of the four glaciers sampled (Tien Shan Glacier No. 1 (TS), Laohugou Glacier No. 12 (LHG), Dongkemadi Glacier (DKMD) and Yulong Mountain $(\mathrm{YL})$ ) and the mass concentration $\left(\mu \mathrm{gC} \mathrm{L}^{-1}\right)$ of dissolved organic carbon (DOC) at the different zones of the glacier (bar plots). 


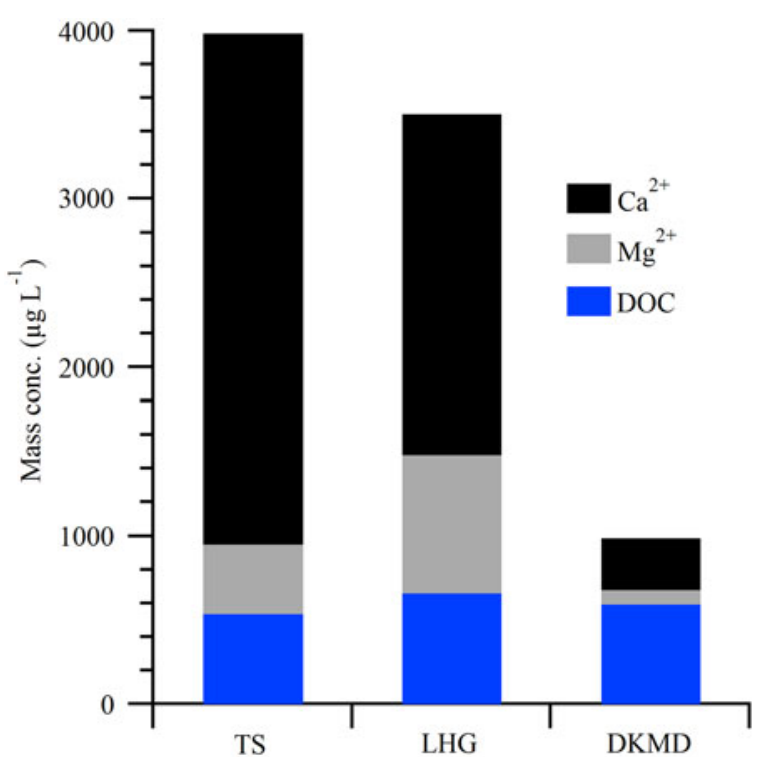

Fig. 2. Comparisons between the concentrations of mineral dust $\left(\mathrm{Ca}^{2+}\right.$ and $\left.\mathrm{Mg}^{2+}\right)$ and dissolved organic carbon (DOC) in snow pit samples from Tien Shan Glacier No. 1 (TS), Laohugou Glacier No. 12 (LHG) and Dongkemadi Glacier (DKMD).

of DOC stored in Chinese glaciers was found to account for $\sim 5.6 \%$ of the total DOC in alpine glaciers (70 $\mathrm{Tg}$ ) around the world (Hood and others, 2015). This is more than the contribution (3.4\%) of Chinese glaciers to the volume of all alpine glaciers. Our estimate for Chinese glaciers is somewhat higher than that of Hood and others (2015), which was based on a lower average DOC concentration $\left(290 \mu \mathrm{gC} \mathrm{L}^{-1}\right)$.

Our estimate on the storage of DOC in Chinese glaciers may represent an upper limit due to the higher DOC concentration during recent decades. Lavanchy and others (1999) show that DOC in ice cores has increased mass concentration in recent decades due to increased anthropogenic emission. In addition, under global warming conditions glacier surfaces may contain higher microbial activity, which increases DOC concentration, than under cold conditions.

\section{ESTIMATING DEPOSITION AND RELEASE RATES OF DOC}

Due to less influence of leaching processes in snow pit samples, we estimated the DOC deposition rate (including both dry and wet deposition) for each region using the average DOC concentration in the snow pit samples, based on:

$$
D=\mathrm{DOC}_{\text {avg }} \times P \times S,
$$

where $D$ is deposition rate, $P$ is annual precipitation rate and $S$ is glacier surface area. The snow pit samples are used to roughly represent one whole year (2013/14) of deposition, based on data from pits previously examined on these glaciers (Xu and others, 2012) and the consistent average concentration of DOC in snow pit samples collected during summer 2014 and 2015 (not shown). Although leaching could occur during summer, uncertainty due to this is difficult to evaluate because it needs continuous in situ observation ( $\mathrm{Li}$ and others, 2006). The average DOC concentration in the $\mathrm{YL}$ surface snow/ice samples $\left(1263.6 \pm 85.2 \mu \mathrm{gC} \mathrm{L}^{-1}\right)$ was used to calculate the deposition rate in the southern part of the TP. We assumed that the average annual accumulation rate for all Chinese glaciers is $500 \mathrm{~mm}$ w.e. (up to $1000 \mathrm{~mm}$ at the southern edge of TP and $300 \mathrm{~mm}$ in the interior TP) (Kaspari and others, 2008), and this gives a total DOC deposition rate for Chinese glaciers of $19.8 \pm$ $1.0 \mathrm{Gg} \mathrm{a}^{-1}$.

The rate at which DOC is released from Chinese glaciers was estimated from the melting rate of glaciers in the high mountains of Asia $\left(-30.6 \pm 5.0 \mathrm{Gt} \mathrm{a}^{-1}\right)(\mathrm{Yi}$ and Sun, 2014) and the average DOC concentration in the samples from all four of our sampling sites $\left(1006.1 \pm 200 \mu \mathrm{gC} \mathrm{L}^{-1}\right)$ based on:

$$
\text { Release rate }=\mathrm{DOC}_{\mathrm{avg}} \times \text { Melting rate of glacier }
$$

The rate at which DOC was released from glaciers in the high mountains of Asia was found to be $\sim 30.8 \pm 6.1 \mathrm{Gg} \mathrm{a}^{-1}$. Chinese glaciers account for $\sim 50 \%$ of all glaciers in the high mountains of Asia (Pfeffer and others, 2014), so the

Table 2. Statistics for glaciers and the storage, deposition and release of DOC in glaciers in four regions of western China. The data for glaciers in each region are cited from the Second Glacier Inventory Dataset of China (Guo and others, 2014)

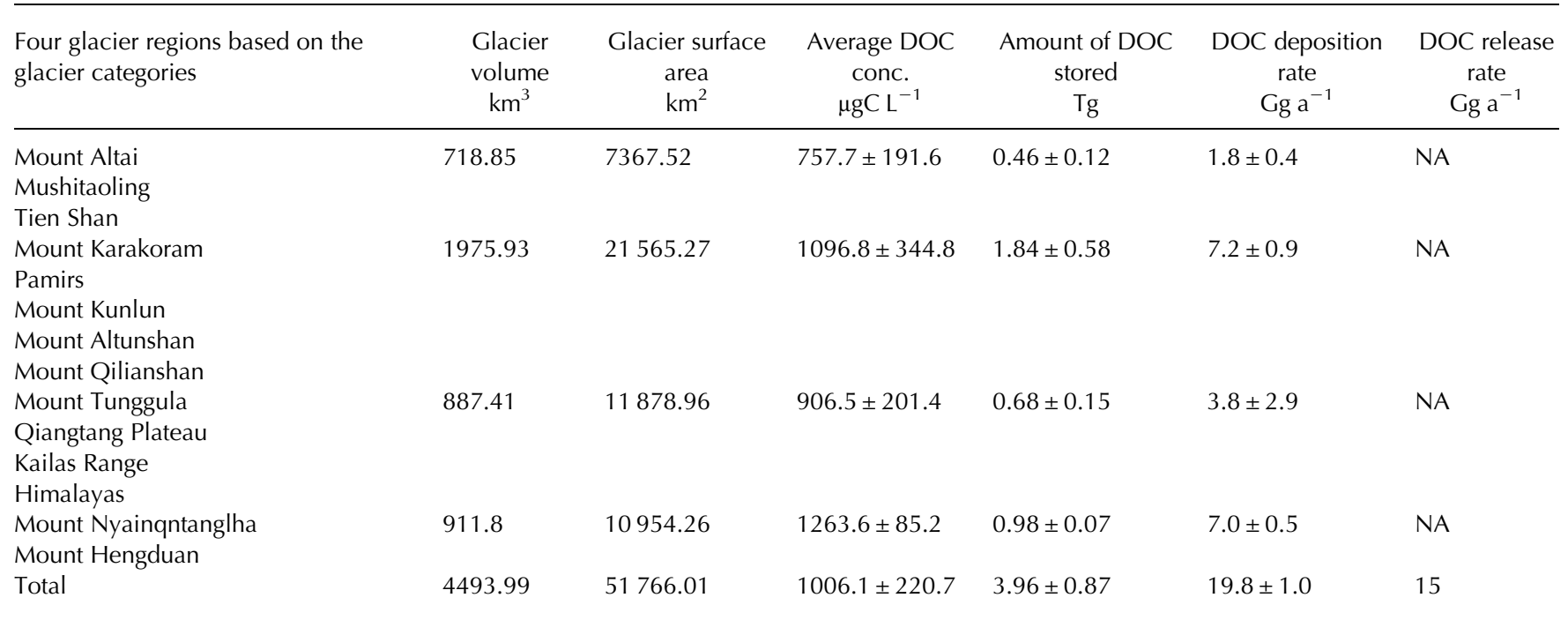


release rate from Chinese glaciers is $\sim 15.4 \pm 6.1 \mathrm{Gg} \mathrm{a}^{-1}$. The difference between the release and deposition rates is $\sim 4.4$ $\mathrm{Gg} \mathrm{a}^{-1}$, so that Chinese glaciers are likely a net weak sink of DOC. The amount of DOC released annually from Chinese glaciers is $\sim 7-20 \%$ of the amount released annually from the Greenland ice sheet (80-220 Gg a ${ }^{-1}$ ) (Bhatia and others, 2013; Hood and others, 2015), while Chinese glaciers total $\sim 0.2 \%$ of the volume of the Greenland ice sheet. It therefore follows that DOC is released more efficiently from Chinese mountain glaciers than from the Greenland ice sheet (Hood and others, 2015).

\section{SUMMARY}

We estimated the amount of DOC stored in glaciers from the latest Chinese inventory and the DOC concentrations in samples collected from four glaciers in different regions. We found that the storage of DOC in Chinese glaciers is $\sim 3.96 \pm 0.87 \mathrm{Tg}$; the deposition and release rates of DOC from Chinese glaciers were $\sim 19.8 \pm 1.0 \mathrm{Gg} \mathrm{a}^{-1}$ and $15.4 \pm$ $6.1 \mathrm{Gg} \mathrm{a}^{-1}$, respectively. Our estimation for the storage of DOC in Chinese glaciers is higher than the results of Hood and others (2015). The release efficiency of DOC based on their glacier volume is higher for Chinese mountain glaciers than for glaciers and ice sheets in polar regions.

\section{ACKNOWLEDGEMENTS}

We thank two anonymous referees for suggestions and advice. We also than Jo Jacka for English editing. This research was supported by grants from the Chinese Academy of Sciences Hundred Talents Program, the National Natural Science Foundation of China Science Fund for Creative Research Groups (41121001), the Key Laboratory of Cryospheric Sciences Scientific Research Foundation (SKLCS-ZZ-2015-01) and the Chinese Academy of Sciences Key Research Program (KJZD-EW-G03).

\section{${ }^{1}$ State Key Laboratory of Cryospheric Sciences, Cold and Arid Regions Environmental and Engineering Research Institute, Chinese Academy of Sciences, Lanzhou 730000, China \\ E-mail: jzxu@/zb.ac.cn}

${ }^{2}$ Institute of Tibetan Plateau Research, Chinese Academy of Sciences, Beijing 100101, China

\section{REFERENCES}

Anesio AM and 6 others (2010) Carbon fluxes through bacterial communities on glacier surfaces. Ann. Glaciol., 51(56), 32-40 (doi: 10.3189/172756411795932092)

Bhatia MP and 5 others (2013) Organic carbon export from the Greenland ice sheet. Geochim. Cosmochim. Ac., 109, 329344 (doi: 10.1016/j.gca.2013.02.006)

Bisutti I, Hilke I and Raessler M (2004) Determination of total organic carbon - an overview of current methods. TrAC Trends Anal. Chem., 23(10-11), 716-726 (doi: 10.1016/j.trac. 2004.09.003)

Guo W and 16 others (2014) The second glacier inventory dataset of China (Version 1.0). Cold and Arid Regions Science Data Center, Lanzhou (doi: 10.3972/glacier.001.2013.db)
Hood E and 6 others (2009) Glaciers as a source of ancient and labile organic matter to the marine environment. Nature, 462(7276), 1044-1047 (doi: 10.1038/nature08580)

Hood E, Battin TJ, Fellman J, O'Neel S and Spencer RGM (2015) Storage and release of organic carbon from glaciers and ice sheets. Nature Geosci., 8(2), 91-96 (doi: 10.1038/ ngeo2331)

Kaspari S and 5 others (2008) Snow accumulation rate on Qomolangma (Mount Everest), Himalaya: synchroneity with sites across the Tibetan Plateau on 50-100 year timescales. J. Glaciol., 54(185), 343-352 (doi: 10.3189/00221430878 4886126)

Lavanchy VMH, Gäggeler HW, Schotterer U, Schwikowski M and Baltensperger $U$ (1999) Historical record of carbonaceous particle concentrations from a European high-alpine glacier (Colle Gnifetti, Switzerland). J. Geophys. Res., 104(D17), 21227-21236 (doi: 10.1029/1999JD900408)

Lawson EC, Bhatia MP, Wadham JL and Kujawinski EB (2014a) Continuous summer export of nitrogen-rich organic matter from the Greenland ice sheet inferred by ultrahigh resolution mass spectrometry. Environ. Sci. Technol., 48(24), 14248-14257 (doi: 10.1021/es501732h)

Lawson EC and 9 others (2014b) Greenland ice sheet exports labile organic carbon to the Arctic oceans. Biogeosciences, 11(14), 4015-4028 (doi: 10.5194/bg-11-4015-2014)

Legrand $M$ and 6 others (2013) Water-soluble organic carbon in snow and ice deposited at Alpine, Greenland, and Antarctic sites: a critical review of available data and their atmospheric relevance. Clim. Past., 9(5), 2195-2211 (doi: 10.5194/cp-92195-2013)

$\mathrm{Li} Z$ and 8 others (2006) Seasonal variability of ionic concentrations in surface snow and elution processes in snow-firn packs at the PGPI site on Ürümqi glacier No. 1, eastern Tien Shan, China. Ann. Glaciol., 43(1), 250-256 (doi: 10.3189/172756406781812069)

Pfeffer WT and 19 others (2014) The Randolph Glacier Inventory: a globally complete inventory of glaciers. J. Glaciol., 60(221), 537552 (doi: 10.3189/2014JoG13J176)

Ramanathan V, Crutzen PJ, Kiehl JT and Rosenfeld D (2001) Aerosols, climate, and the hydrological cycle. Science, 294 (5549), 2119-2124 (doi: 10.1126/science.1064034)

Shi Y and Liu S (2000) Estimation on the response of glaciers in China to the global warming in the 21st century. Chinese Sci. Bull., 45(7), 668-672 (doi: 10.1007/BF02886048)

Singer GA and 6 others (2012) Biogeochemically diverse organic matter in Alpine glaciers and its downstream fate. Nature Geosci., 5(10), 710-714 (doi: 10.1038/ngeo1581)

Spencer RGM and 6 others (2014) Source and biolability of ancient dissolved organic matter in glacier and lake ecosystems on the Tibetan Plateau. Geochim. Cosmochim. Ac., 142, 64-74 (doi: 10.1016/j.gca.2014.08.006)

Spracklen DV and 12 others (2011) Aerosol mass spectrometer constraint on the global secondary organic aerosol budget. Atmos. Chem. Phys., 11(23), 12109-12136 (doi: 10.5194/acp-11-121092011)

Stubbins A and 13 others (2012) Anthropogenic aerosols as a source of ancient dissolved organic matter in glaciers. Nature Geosci., 5(3), 198-201 (doi: 10.1038/ngeo1403)

Takeuchi N and Li Z (2008) Characteristics of surface dust on Ürümqi Glacier No. 1 in the Tien Shan Mountains, China. Arct. Antarct. Alp. Res., 40(4), 744-750 (doi: 10.1657/15230430(07-094)[TAKEUCHI]2.0.co;2)

$\mathrm{Xu}$ J and 6 others (2012) Sr-Nd isotope evidence for modern aeolian dust sources in mountain glaciers of western China. J. Glaciol., 58 (211), 859-865 (doi: 10.3189/2012JoG12J006)

$\mathrm{Xu}$ J and 6 others (2013) Dissolved organic matter and inorganic ions in a Central Himalayan Glacier - insights into chemical composition and atmospheric sources. Environ. Sci. Technol., 47(12), 6181-6188 (doi: 10.1021/es4009882)

$\mathrm{Xu}$ J and 5 others (2015) Chemical composition and size distribution of summertime PM2.5 at a high altitude remote location in the 
northeast of the Qinghai-Xizang (Tibet) Plateau: insights into aerosol sources and processing in free troposphere. Atmos. Chem. Phys., 15(9), 5069-5081 (doi: 10.5194/acp-15-50692015)

Yao T and 14 others (2012) Different glacier status with atmospheric circulations in Tibetan Plateau and surroundings. Nature Clim. Change, 2(9), 663-667 (doi: 10.1038/nclimate1580)
Yi S and Sun W (2014) Evaluation of glacier changes in high-mountain Asia based on 10 year GRACE RL05 models. J. Geophys. Res., 119(3), 2013JB010860 (doi: 10.1002/2013JB010860)

Zhang R and 8 others (2015) Quantifying sources, transport, deposition, and radiative forcing of black carbon over the Himalayas and Tibetan Plateau. Atmos. Chem. Phys., 15(11), 6205-6223 (doi: 10.5194/acp-15-6205-2015)

MS received 4 October 2015 and accepted in revised form 17 January 2016; first published online 19 April 2016 